\title{
Dominant-Negative Subunits Reveal Potassium Channel Families That Contribute to M-Like Potassium Currents
}

\author{
A. A. Selyanko, ${ }^{1 \dagger}$ P. Delmas, ${ }^{1}$ J. K. Hadley, ${ }^{1}$ L. Tatulian, ${ }^{1}$ I. C. Wood, ${ }^{1}$ M. Mistry, ${ }^{1}$ B. London, ${ }^{2}$ and \\ D. A. Brown ${ }^{1}$ \\ ${ }^{1}$ Department of Pharmacology, University College London, London WC1E 6BT, United Kingdom, and ${ }^{2}$ Cardiovascular \\ Institute, University of Pittsburgh Medical Center, Pittsburgh, Pennsylvania 15213
}

$\mathrm{M}$-currents are $\mathrm{K}^{+}$currents generated by members of the KCNQ family of $\mathrm{K}^{+}$channels (Wang et al., 1998). However, in some cells, M-like currents may be contaminated by members of other $\mathrm{K}^{+}$channel gene families, such as the erg family (Meves et al., 1999; Selyanko et al., 1999). In the present experiments, we have used the acute expression of poredefective mutants of KCNQ3 (DN-KCNQ3) and Merg1a (DNMerg1a) as dominant negatives to separate the contributions of these two families to M-like currents in NG108-15 neuroblastoma hybrid cells and rat sympathetic neurons. Two kinetically and pharmacologically separable components of M-like current could be recorded from NG108-15 cells that were individually suppressed by DN-Merg1a and DN-KCNQ3, respectively. In contrast, only DN-KCNQ3, and not DN-Merg1a, reduced cur- rents recorded from sympathetic neurons. Pharmacological tests suggested that the residual current in DN-KCNQ3-treated sympathetic neurons was carried by residual KCNQ channels. Ineffectiveness of DN-Merg1a in sympathetic neurons was not caused by lack of expression, as judged by confocal microscopy of Flag-tagged DN-Merg1a. These results accord with previous inferences regarding the roles of erg and KCNQ channels in generating M-like currents. This experimental approach should therefore be useful in delineating the contributions of members of these two gene families to $\mathrm{K}^{+}$currents in other cells.

Key words: M-current; KCNQ channels; erg channels; dominant negative; NG108-15 cells; sympathetic neurons
M-currents are low-threshold, noninactivating $\mathrm{K}^{+}$currents that regulate neuronal excitability and firing behavior (Brown and Adams, 1980; Brown, 1988; Marrion, 1997). The M-current in rat sympathetic neurons has been attributed to current flow through heteromeric channels composed of KCNQ2 and KCNQ3 subunits (Wang et al., 1998; Shapiro et al., 2000). However, other members of the KCNQ family also generate M-like currents (Kubisch et al., 1999; Lerche et al., 2000; Schroeder et al., 2000; Selyanko et al., 2000). Furthermore, in neuroblastoma hybrid cells a component of the M-like current originally reported (Brown and Higashida, 1988; Robbins et al., 1992) appears to be carried by Merg1a, a product of the ether-a-go-go-related gene family (Meves et al., 1999; Selyanko et al., 1999). Hence, the molecular composition of "M-like" currents may vary in different neurons and neuronal cell types, suggesting the need for appropriate methods for their molecular dissection.

In the present experiments we have tested whether the contri-

\footnotetext{
Received Oct. 24, 2001; revised Dec. 13, 2001; accepted Dec. 17, 2001.

This work was supported by grants from the UK Medical Research Council, the Wellcome Trust, European Union Grant QLG3-1999-00827, and by National Institutes of Health, National Heart, Lung, and Blood Institute Grant R01HL58030. We are grateful to Dr. T. J. Jentsch (Zentrum für Molekulare Neurobiologie Hamburg, D-20246, Hamburg, Germany) and his colleagues for kindly providing KCNQ3 (G318S) cDNA.

$\dagger$ Deceased, September 23, 2001

Correspondence should be addressed to D. A. Brown, Department of Pharmacology, University College London, Gower Street, London, WC1E 6BT UK. Email: d.a.brown@ucl.ac.uk.

P. Delmas' present address: Integration des Information Sensorielles-Centre National de la Recherche Scientifique, 31 Chemin J. Aiguier, 13402 Marseille cedex 20, France.

I. C. Wood's present address: School of Biochemistry and Molecular Biology, University of Leeds, Leeds LS2 9DT, UK.

Copyright (C) 2002 Society for Neuroscience $\quad 0270-6474 / 02 / 220001-05 \$ 15.00 / 0$
}

butions of products of KCNQ and erg gene families to M-like currents in sympathetic neurons and neuroblastoma hybrid cells can be identified by using pore-defective mutants of KCNQ3 and Merg1a as potential dominant negatives. The Merg1a mutant Merg1a(G628S) has been reported to suppress HERG currents in cardiac cells (Babij et al., 1998; Hoppe et al., 2001), whereas the KCNQ3 mutant KCNQ3(G318S) suppresses heteromeric KCNQ2 + KCNQ3 currents (Schroeder et al., 1998) and homomeric KCNQ4 and KCNQ5 currents (Kubisch et al., 1999; Schroeder et al., 2000) when expressed in frog oocytes.

\section{MATERIALS AND METHODS}

DNA plasmids. Plasmids were constructed as described previously (Abogadie et al., 1997). KCNQ3(G318S) cDNA was provided by Dr. T. J. Jentsch [Zentrum für Molekulare Neurobiologie Hamburg (ZMNH), Hamburg, Germany]. The sequence was amplified from the template, pTLN KCNQ3(G318S) (Schroeder et al., 1998) using the primers KCNQ3 3s Flag 5'-AGAGGATCCGATGGACTACAAGGACGACGATGACAAGGGGCTCAAGGCGCGCAGGGC and KCNQ3 2615a Xba 5'-GAGATCTAGAAATGGGCTTATTGGAAGG. The resulting

This article is published in The Journal of Neuroscience, Rapid Communications Section, which publishes brief, peerreviewed papers online, not in print. Rapid Communications are posted online approximately one month earlier than they would appear if printed. They are listed in the Table of Contents of the next open issue of JNeurosci. Cite this article as: JNeurosci, 2002, 0:RC212 (1-5). The publication date is the date of posting online at www.jneurosci.org.

http://www.jneurosci.org/cgi/content/full/6139 

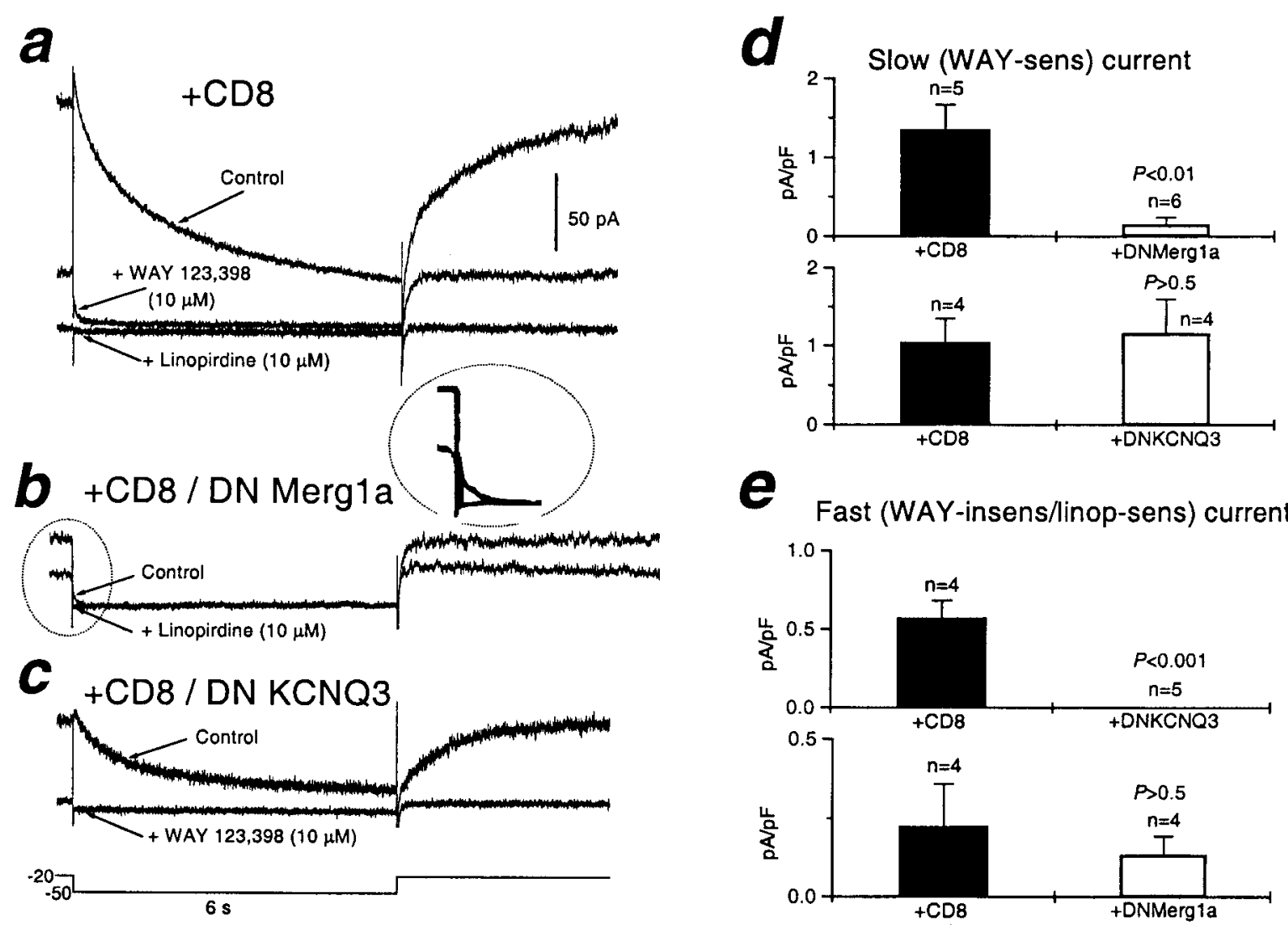

Figure 1. Slow and fast components of M-like current in NG108-15 neuroblastoma x glioma hybrid cells are selectively suppressed by dominant-negative Merg1a and KCNQ3 constructs, respectively. Differentiated NG108-15 cells were transfected with plasmids containing cDNAs expressing CD8 alone (controls) or with additional cDNA plasmids encoding Merg1a(G628S) (DN-Merg1a) or KCNQ3(G318S) (DN-KCNQ3). Currents were recorded 1-2 $\mathrm{d}$ after transfection from cells expressing CD8 using the amphotericin B perforated-patch variant of the whole-cell patch-clamp technique. $a-c$, Deactivation of M-like currents on stepping for $6 \mathrm{sec}$ from a holding potential of -20 to $-50 \mathrm{mV}$. Control currents $(a)$ showed two components of deactivation, fast and slow. Addition of $10 \mu \mathrm{M}$ WAY 123,398 abolished the slow component (middle trace) and superimposed addition of $10 \mu \mathrm{M}$ linopirdine abolished the residual fast component (bottom trace). $b$, Deactivation current recorded from a cell cotransfected with DN-Merg1a cDNA showed only a fast component, abolished by linopirdine. $c$, Deactivation current from a cell cotransfected with DN-KCNQ3 cDNA was slow and completely abolished by WAY 123,398. The inset in $b$ shows the linopirdine-sensitive current on a faster time-base. $d$, $e$, Amplitudes of deactivation tail currents recorded from cells expressing CD8 alone ( filled bars) or with cotransfection of DN-Merg1a or DN-KCNQ3. $d$, Amplitude of that component inhibited by $10 \mu \mathrm{M}$ WAY 123,398. e, Amplitude of that component inhibited by $10 \mu \mathrm{M}$ linopirdine. Individual components were determined by subtracting residual current after blockade from initial current (Selyanko et al., 1999). Blocks and bars show means \pm SEM of the number of cells $(n)$ indicated.

PCR product was purified, digested with $B a m \mathrm{HI}$ and $X b a \mathrm{I}$, and ligated into BamHI-XbaI cut pCS2+ MT to produce pFL KCNQ3 (G318S). An antisense oligo containing a single nucleotide substitution was used to produce a PCR fragment containing the Merg1a(G628S) mutation. The segment between the $B g l$ II and BsteII restriction sites in the wild-type Merg1a plasmid (London et al., 1997) was then replaced by this mutant fragment to generate Merg1a(G628S). Plasmid clones were verified by DNA sequencing.

Cell culture. NG108-15 mouse neuroblastoma x rat glioma cells were differentiated and cultured as described by Robbins et al. (1992). Sympathetic neurons were isolated from the superior cervical ganglia (SCG) of humanely killed 17- to 19-d-old Sprague Dawley rats and cultured using standard procedures as described previously (Delmas et al., 1998).

Transfection. After differentiation, NG108-15 cells were transfected with cDNA plasmids encoding Merg1a (G628S) or KCNQ3(G318S), together with a plasmid coding for CD8 in a ratio of 10:1, using Lipofectamine Plus (Invitrogen, Gaithersburg, MD). Cells expressing CD8, identified by adding CD8-binding Dynabeads (Dynal, Great Neck, NY), were used for recording 1-2 d later.

Microinjection. cDNA plasmids were diluted to $200-400 \mu \mathrm{g} / \mathrm{ml}$ in a $\mathrm{Ca}^{2+}$-free solution containing (in $\mathrm{mM}$ ): $140 \mathrm{KCl}, 1 \mathrm{MgCl}_{2}$, and 10 HEPES, $290 \mathrm{mOsm} / 1, \mathrm{pH} 7.3$, plus fluorescein isothiocyanate-conjugated dextran (70 kDa; Molecular Probes, Leiden, The Netherlands) and microinjected into the nuclei of sympathetic neurons after 1-2 d in culture. Fluorescein-labeled neurons were used for recording $1 \mathrm{~d}$ later.

Electrophysiology. Cells were bathed in (mM): $\mathrm{NaCl} \mathrm{120,} \mathrm{KCl} 3$,
HEPES 5, $\mathrm{NaHCO}_{3} 23$, glucose $11, \mathrm{MgCl}_{2} 1.2, \mathrm{CaCl}_{2} 2.5$, and tetrodotoxin 0.0005 , pH 7.4. Membrane currents were recorded from CD38expressing NG108-15 cells or fluorescein-labeled SCG neurons using amphotericin-perforated patch electrodes. The composition of the electrode solutions were (mM), for NG108-15 cells: $\mathrm{K}$ acetate $90 ; \mathrm{KCl} 20$, HEPES 40, $\mathrm{MgCl}_{2}$ 3, EGTA 3, and $\mathrm{CaCl}_{2} 1$; and for SCG neurons: $\mathrm{K}$ acetate $80 ; \mathrm{KCl} 30, \mathrm{HEPES} 40$, and $\mathrm{MgCl}_{2} 3$. Solutions were adjusted to $\mathrm{pH} 7.3-7.4$ with $\mathrm{KOH}$ and to $280 \mathrm{mOsmol} / 1$ with $\mathrm{K}$ acetate. Electrode resistances were 2-4 M $\Omega$; access resistances after amphotericin perforation were 6-8 M $\Omega$. Currents were recorded using Axopatch 200A amplifiers (Axon Instruments, Foster City, CA), filtered at $1 \mathrm{kHz}$, and digitized at $1-10 \mathrm{kHz}$. Data were collected and analyzed using pClamp7 software (Axon Instruments) and expressed as means \pm SEM. Statistical comparisons were performed using Student's $t$ test, and differences were considered significant at $p<0.05$.

Single-cell PCR. Cytosol from single sympathetic neurons was collected into $4 \mu \mathrm{l}$ of first strand buffer [50 mM Tris- $\mathrm{HCl}, \mathrm{pH} 8.3,75 \mathrm{~mm}$ $\mathrm{KCl}, 3 \mathrm{mM} \mathrm{MgCl}, 0.5 \%$ Nonidet P-40, $10 \mu \mathrm{M}$ each dNTP, $0.92 \mu \mathrm{M}$ oligo-dT ${ }_{15}$ (Promega, Madison, WI), and 20-100 U of RNase Inhibitor (Roche Products, Hertfordshire, UK)] and denatured at $65^{\circ} \mathrm{C}$ for $1 \mathrm{~min}$. Reverse transcription was performed using $100 \mathrm{U}$ of Moloney murine leukemia virus reverse transcriptase, RNase $\mathrm{H}(-)$ point mutant (Promega) at $37^{\circ} \mathrm{C}$ for $15 \mathrm{~min}$. Gene-specific PCRs were then performed using $2 \mu \mathrm{l}$ of either cDNA or amplified cDNA template. Primer pairs used were, for erg: erg-s 5' CCCYTTCAAGGCMGTGTGGG and erg-a 5' CTGGTHAGRCTGCTGAAGGT; for rKCNQ2:2900s AGTGCG- 
GATCAG AGTCTC/3126a GCTCTGATGCTGACTTTGAGGC; and for rKCNQ3: 746s CAGCAAAGAACTCATCACCG/906a ATGGTGGCCAGTGTGATCAG. Amplified cDNA template was generated as described by Brady and Iscove (1993). Briefly, a poly d(A) tract 5' priming site was added by a terminal deoxynucleotidyl transferase reaction followed by PCR amplification using RACE1 primer (GAC TCG AGT CGA CAT CGA $\mathrm{T}_{(17)}$ ). Cycling conditions were: 25 cycles at $94^{\circ} \mathrm{C}$ for $1 \mathrm{~min}, 42^{\circ} \mathrm{C}$ for $2 \mathrm{~min}$, and $72^{\circ} \mathrm{C}$ for 6 min followed by 25 cycles at $94^{\circ} \mathrm{C}$ for $1 \mathrm{~min}, 42^{\circ} \mathrm{C}$ for $1 \mathrm{~min}$, and $72^{\circ} \mathrm{C}$ for $2 \mathrm{~min}$.

Immunocytochemistry. Flag-tagged Merg1a(G618S) and flag-tagged KCNQ3(G318S) constructs were microinjected into neurons as described above. One or two days after injection, neurons were fixed in $4 \%$ paraformaldehyde in PBS for $20 \mathrm{~min}$, rinsed for $5 \mathrm{~min}$ in PBS, and permeabilized in $0.1 \%$ Triton for $5 \mathrm{~min}$. Primary anti-flag monoclonal antibody was incubated for $1 \mathrm{hr}$ and used at a dilution of 1:50. After washing, cells were incubated with either FITC- or Texas Redconjugated anti-mouse IgGs (1:100) for $30 \mathrm{~min}$ at room temperature, mounted, and observed using epifluorescent illumination. Immunocytochemical localization of untagged erg1 was performed using an antibody against a synthetic peptide corresponding to the last 14 amino acids of merg1a (identical to rat erg1) at 1:800 dilution, as described in Selyanko et al. (1999), except that TRITC- and FITC-conjugated secondary antibodies (Molecular Probes) were used at 1:100 or 1:200 dilution. For tau protein staining, the antibody (Calbiochem, La Jolla, CA) was used at 1:800 dilution.

Drugs and chemicals. Linopirdine (DuP 996) was obtained from Research Biochemicals (Natick, MA). WAY 123,398 was provided by Wyeth-Ayerst Research (Princeton, NJ). The mutant KCNQ3(G318S) was kindly provided by Dr. T. J. Jentsch (ZMNH, Hamburg, Germany).

\section{RESULTS}

\section{NG108-15 neuroblastoma hybrid cells}

M-like currents were recorded from these cells by predepolarizing the cells to $-20 \mathrm{mV}$ to preactivate currents, then hyperpolarizing the cells for $6 \mathrm{sec}$ period to deactivate the currents (Fig. 1). As previously reported (Selyanko et al., 1999), deactivation currents showed two main components: a slow component that was selectively suppressed by $10 \mu \mathrm{M}$ WAY 123,398 and a fast component that was annulled by $10 \mu \mathrm{M}$ linopirdine (Fig. 1a). It was previously suggested that the slow component of deactivation reflected current through Merg1a channels, whereas the fast component referred to current through KNCQ channels (Selyanko et al., 1999; see also Meves et al., 1999).

To test the effect of the putative dominant-negative constructs Merg1a(G628S) and KCNQ3(G318S) (hereafter abbreviated to DN-Merg1a and DN-KNCQ3), deactivation currents in cells previously transfected with these constructs were analyzed into slow and fast components as described previously (Selyanko et al., 1999) and then re-recorded and re-analyzed after the addition of WAY 123,398 and subsequent addition of linopirdine (still in the presence of WAY 123,398). As shown in Figure 1, $a$ and $d$, cells previously transfected with DN-Merg1a showed negligible slow (WAY 123,398-sensitive) component to the deactivation currents. Instead, only a fast component could be detected, not significantly different in average amplitude to that in control (CD8transfected) cells, which was insensitive to WAY 123,398 and completely inhibited by linopirdine. In contrast, currents recorded from cells transfected with DN-KCNQ3 showed only a slow component to their deactivation; this current was of comparable amplitude to the slow component recorded from control cells and was completely inhibited by WAY 123,398 (Fig. 1c-e).

\section{Sympathetic (SCG) neurons}

Native M currents in SCG neurons were recorded by predepolarizing to $-20 \mathrm{mV}$ and deactivated by progressive $10 \mathrm{mV}$ hyperpolarizing steps down to $-80 \mathrm{mV}$ (Fig. $2 a$ ). The amplitude of the current was measured from the extrapolated initial amplitude of
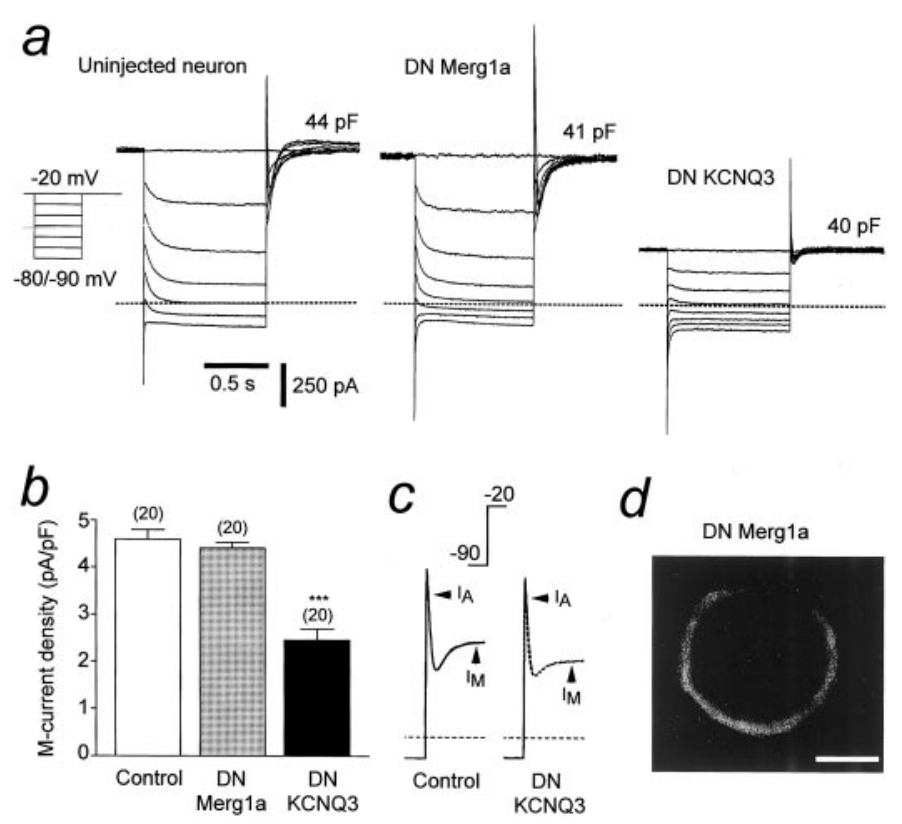

Figure 2. M-currents in rat sympathetic neurons are reduced by expressing DN-KCNQ3 but not by DN-Merg1a. Sympathetic neurons were dissociated from isolated rat superior cervical ganglia and injected intranuclearly with plasmids containing cDNAs coding for either DNKCNQ3 or DN-Merg1a, with fluorescein-labeled dextran as marker. M-currents were recorded after culturing for 1-2 d. $a$, Records show families of deactivation tail currents on stepping from a holding potential of -20 to -80 or $-90 \mathrm{mV}$ in $10 \mathrm{mV}$ steps, recorded from an uninjected cell, and from cells preinjected with DN-Merg1a or DN-KCNQ3 cDNAs respectively. Dashed line, Zero current. Cell capacitances (in picofarads) are noted. $b$, Mean M-current density (in picoamperes per picofarad) \pm SEM (number of cells in parentheses) in control (uninjected) neurons and in neurons preinjected with DN-Merg1a or DN-KCNQ3 cDNAs. ${ }^{* * *} p<$ 0.01 (Student's $t$ test). $c$, Transient A-currents recorded on stepping from -90 to $-20 \mathrm{mV}$ from an uninjected (control) cell and from a cell injected with DN-KCNQ3 cDNA. $d$, Immunocytochemical localization of Flagtagged DN-Merg1a. Scale bar, $10 \mu \mathrm{m}$.

the deactivation tail current at $-50 \mathrm{mV}$. As previously reported, deactivation was rapid, and currents were completely inhibited by linopirdine (Lamas et al., 1997; Wang et al., 1998; Selyanko et al., 1999). Current amplitudes were unaffected in cells previously injected with the DN-Merg1a construct, but were significantly reduced by approximately half $(47 \%)$ in cells previously injected with the DN-KCNQ3 construct (Fig. 2a,b). The lack of effect of the DN-Merg1a construct was not caused by lack of expression, because ample staining for the corresponding Flag-tagged protein could be detected in or near to the cell membrane (Fig. 2c). mRNA for both erg1 and erg 3 have previously been reported in total cellular RNA extracts from rat SCG neurons (Shi et al., 1997). However, no erg1 mRNA could be detected in the dissociated SCG neurons used in the present experiments by singlecell PCR (Fig. 3a), whereas clear signals could be obtained for KCNQ2 and KCNQ3 (Fig. 3b). Furthermore, negligible immunostaining of erg1 protein could be detected (Fig. 3c) using an antibody that strongly stained differentiated NG108-15 cells (Selyanko et al., 1999) and erg1-expressing Chinese hamster ovary (CHO) cells (Fig. $3 d$ ). This accords with the previously reported lack of staining for erg1 in dissociated mouse SCG neurons (Selyanko et al., 1999).

DN-KCNQ3 had no significant effect on the amplitude of the transient A-type $\mathrm{K}^{+}$current $\left(I_{\mathrm{A}}\right)$ in these cells (Fig. $3 c$ ). Mean 

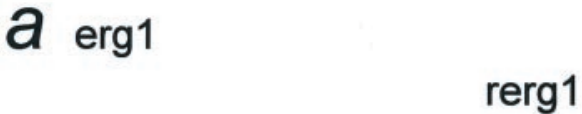

\section{$b$ KCNQ2}

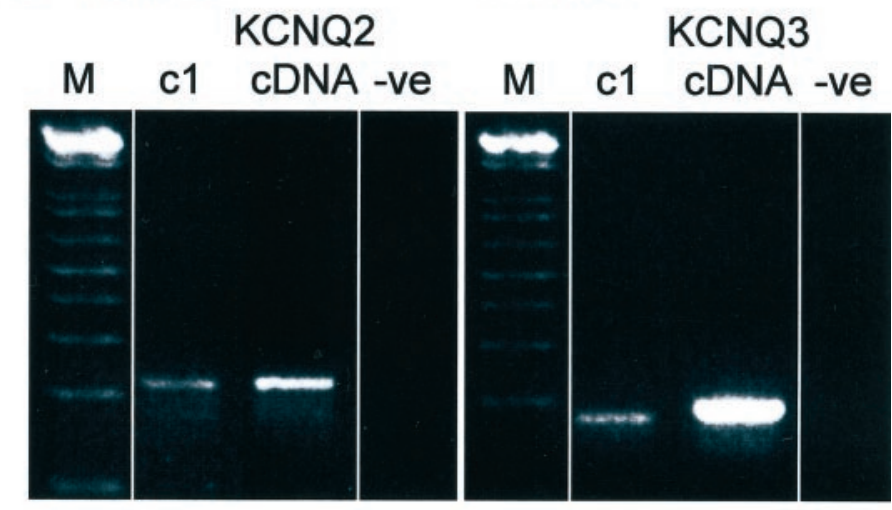

KCNQ3
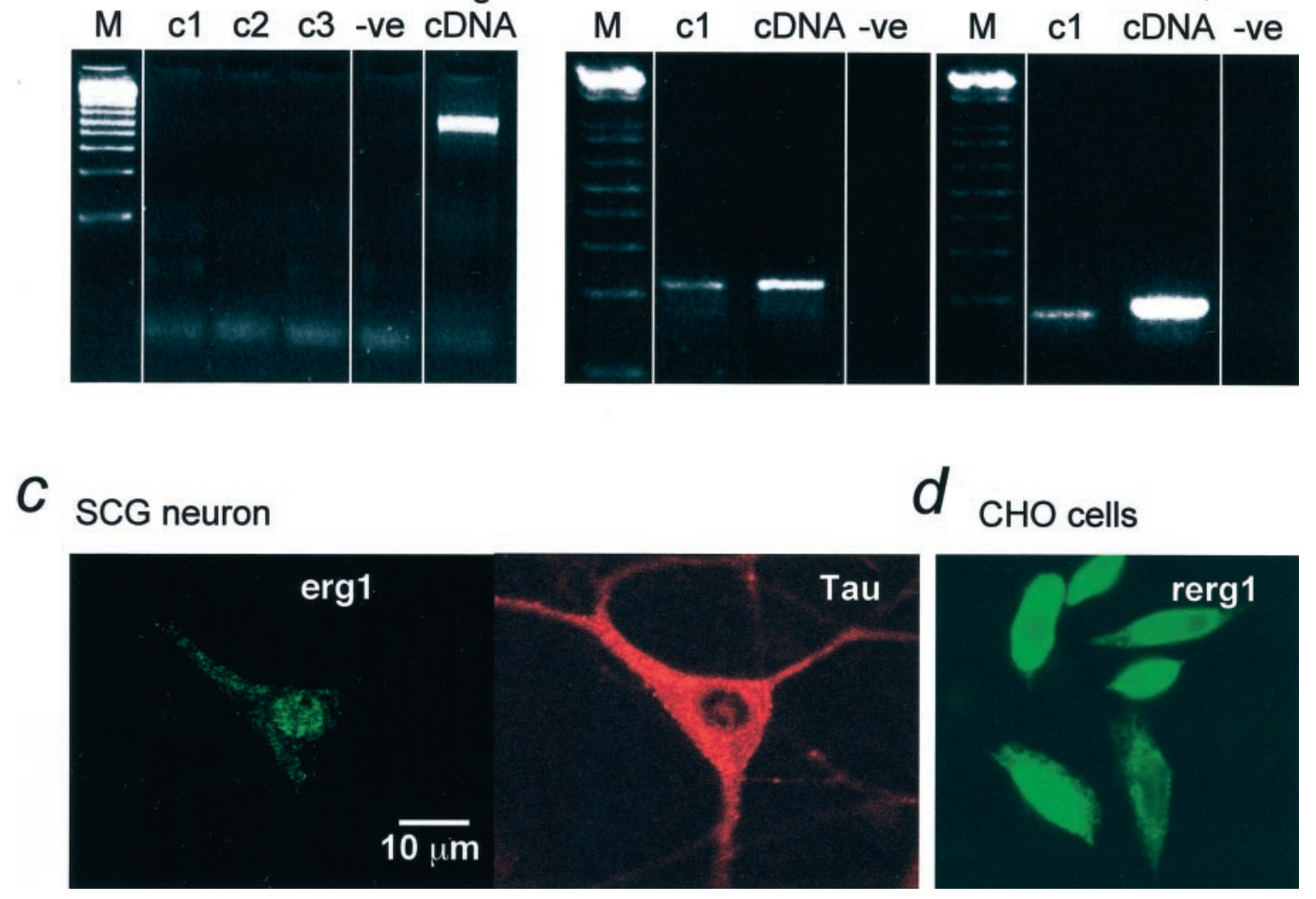

Figure 3. Dissociated SCG neurons do not express erg1 channels. $a$, $b$, Single-cell PCR of SCG neurons using primers for rat erg1 (rerg1) ( $a$ ) and rat KCNQ2 and KCNQ3 $(b)$. Three cells $(c 1-c 3)$ were tested in $a$, and one each $(c 1)$ in $b$. Control reactions were performed using cDNA sequences encoding rat erg1 or KCNQ2 or 3 as indicated. $-v e$, No template; $M, 1 \mathrm{~Kb}$ plus ladder. $c$, $d$, Immunostaining for erg1 protein (see Materials and Methods). $c$, Coimmunostaining for erg1 (left, green) and tau protein (right, red) in a sympathetic neuron. $d$, Immunostaining of a CHO cell transfected with rat erg1 cDNA.

current densities (in picoamperes per picofarad) were: controls, $19.5 \pm 2.0(n=7)$; DN-KCNQ3-expressing, $18.2 \pm 3.5(n=7)$.

The residual M-like current in DN-KCNQ3-expressing cells was clearly carried by KCNQ channels because it was blocked by linopirdine, with an $\mathrm{IC}_{50}$ of $5.5 \mu \mathrm{M}(n=4)$, comparable with previously reported values for KCNQ currents (Wang et al., 1998) and native M-currents in these cells (Lamas et al., 1997). It might therefore have been attributable to incomplete replacement of wild-type KCNQ3 subunits in native KCNQ2/3 M channels or to residual current carried by KCNQ2 homomultimers. To test the latter, we assessed the sensitivity of the residual current to tetraethylammonium (TEA), because currents generated by KCNQ2 homomultimers are $\sim 10$ times more sensitive to TEA than are heteromeric KCNQ2/3 currents (Wang et al., 1998; Hadley et al., 2000; Shapiro et al., 2000). The $\mathrm{IC}_{50}$ for the residual current $(8.5 \pm 1.8 \mathrm{~mm} ; n=5)$ was not significantly different from that for control cells $(4.5 \pm 1.3 \mathrm{~mm} ; n=6)$, or from previously reported values for KCNQ2/3 currents (5.8 mM, Wang et al., 1998; $3.8 \mathrm{~mm}$, Hadley et al., 2000).

\section{DISCUSSION}

The principal point that emerges from these experiments is that pore-defective mutants of Merg1a and KCNQ3 can be used effectively as acute dominant-negative "knock-downs" to dissect the contributions of members of the erg and $\mathrm{KCNQ}$ families to
M-like $\mathrm{K}^{+}$currents in neurons and neuronal cells. Thus, acute expression of DN-Merg1a [Merg1a(G628S)] and DN-KCNQ3 [KCNQ3(G628S)] produced a very sharp delineation of the separate contributions of currents through erg and KCNQ channels to the trajectories of the compound deactivation of the M-like current in NG108-15 neuroblastoma hybrid cells, which fully accorded with previous conclusions derived from kinetic and pharmacological analysis (Meves et al., 1999; Selyanko et al., 1999).

In contrast, and in spite of clear evidence for expression of the appropriate protein (Fig. 2c), DN-Merg1a had no effect on the M current recorded from sympathetic ganglion cells. This is because erg1 was not expressed in these neurons and does not contribute to their M-like current. Thus (and notwithstanding the previous detection of erg1 and erg3 mRNA in whole ganglion RNA; Shi et al., 1997), neither erg1 mRNA nor erg1 protein could be detected in single dissociated rat SCG neurons under the present experimental conditions by single cell PCR or immunocytochemistry (Fig. 3). This accords with observations that the ganglionic $\mathrm{M}$ current can be completely inhibited by the KCNQ channel blocking agent linopirdine (Lamas et al., 1997; Wang et al., 1998; Selyanko et al., 1999) and is insensitive to the erg channel blocking agent WAY 123,398 (Selyanko et al., 1999) (A. A. Selyanko, unpublished observations). The signals detected by Shi et al. 
(1997) might therefore have derived from non-neural elements in the ganglion.

Inhibition of the ganglionic M current by DN-KCNQ3 was not complete. One cause of this might be substitution of homomeric $\mathrm{KCNQ} 2$ channels for the native $\mathrm{KCNQ} 2 / 3$ heteromultimers. Because homomeric KCNQ2 channels are at least 10 times more sensitive to TEA than are heteromeric KCNQ2/3 channels (Wang et al., 1998; Hadley et al., 2000; Shapiro et al., 2000), an increased contribution of KCNQ2 subunits should be revealed by an increased sensitivity of the residual current to TEA in DNKCNQ3-treated cells. However, no significant change in TEA sensitivity was detected so the residual current appeared to be carried by the same combination of subunits as that generating the native $\mathrm{M}$ current. The most likely cause of the incomplete inhibition is therefore that the DN-KCNQ3 protein was not expressed at sufficient levels, or for sufficient time, to completely substitute for wild-type KCNQ3 subunits in the KCNQ2/3 heteromultimers that constitute the native $\mathrm{M}$ channels. The differential effectiveness of the DN-KCNQ3 construct on NG108-15 and SCG cells might reflect the different efficiencies of the methods (transfection vs microinjection) used to express the construct and/or different expression times ( $1 \mathrm{~d}$ vs $2 \mathrm{~d}$ ) used. (Longer expression times could not be used for SCG neurons because of poor survival.)

When expressed homomerically, all KCNQ gene products form "M channels", as defined kinetically and pharmacologically (Lerche et al., 2000; Schroeder et al., 2000; Selyanko et al., 2000). NG108-15 cells and rat sympathetic neurons express mRNAs for at least three such gene products: KCNQ2, 3, and 5 (Wang et al., 1998; Schroeder et al., 2000). Furthermore, KCNQ3 coassembles with KCNQ2, KCNQ3, KCNQ4, and KCNQ5, such that DN-KCNQ3 suppresses currents carried by all of them, including those generated by homomeric expression of KCNQ4 or KCNQ5 subunits (Schroeder et al., 1998, 2000; Kubisch et al., 1999). Hence, current suppression by DN-KCNQ3 does not define the particular KCNQ subunit combination that generates the $M$ current. On the contrary, the advantage of this construct is that it can reveal the contribution of KCNQ channels to neuronal M-like currents irrespective of subunit composition. This action appears to be specific to KCNQ channels in so far that there was no parallel reduction of the transient "A-current": instead, the fast-inactivating component of this current is suppressed by expressing a dominant-negative Kv4.2 construct (Malin and Nerbonne, 2000). Thus, this acute knock-down approach provides a potentially valuable tool for assessing the relative contributions of $\mathrm{KCNQ}$ and erg (or other) family gene products to neural $\mathrm{K}^{+}$ currents.

\section{REFERENCES}

Abogadie FC, Vallis Y, Buckley NJ, Caulfield MP (1997) Use of antisense-generating plasmids to probe the function of signal transduction proteins in primary neurons. In: Methods in molecular biology, Vol 83 (Challis RAJ, ed), pp 217-225. Totowa, NJ: Humana.

Babij P, Askew GR, Nieuwenhuijsen B, Su C-M, Bridal TR, Jow B, Argentieri TM Kulik J, DeGennaro LJ, Spinelli W, Colatsky TJ (1998) Inhibition of cardiac delayed rectifier $\mathrm{K}^{+}$current by overexpression of the long-QT syndrome HERG G628S mutation in transgenic mice. Circ Res 83:668-678.

Brady G, Iscove NN (1993) Construction of cDNA libraries from single cells. Methods Enzymol 225:611-624.

Brown DA (1988) M-currents. In: Ion channels, Vol 1 (Narahashi T, ed), pp 55-99. New York: Plenum.

Brown DA, Adams PR (1980) Muscarinic suppression of a novel voltage-sensitive $\mathrm{K}^{+}$current in a vertebrate neuron. Nature 283:673-676.

Brown DA, Higashida H (1988) Voltage- and calcium-activated potassium currents in mouse neuroblastoma $\mathrm{x}$ rat glioma hybrid cells. J Physiol (Lond) 397:149-165.

Delmas P, Brown DA, Dayrell M, Abogadie FC, Caulfield MP, Buckley NJ (1998) On the role of endogenous G-protein $\beta \gamma$ subunits in N-type $\mathrm{Ca}^{2+}$ current inhibition by neurotransmitters in rat sympathetic neurones. J Physiol (Lond) 506:319-329.

Hadley JK, Noda M, Selyanko AA, Wood IC, Abogadie FC, Brown DA (2000) Differential tetraethylammonium sensitivity of KCNQ1-4 potassium channels. Br J Pharmacol 129:413-415.

Hoppe UC, Marban E, Johns D (2001) Distinct gene-specific mechanisms of arrhythmia revealed by cardiac gene transfer of two long QT disease genes, HERG and KCNE1. Proc Natl Acad Sci USA 98:5335-5340.

Kubisch C, Schroede BC, Friedrich T, Lutjohann B, El-Amraoui A, Marlin S, Petit C, Jentsch TJ (1999) KCNQ4, a novel potassium channel expressed in sensory outer hair cells, is mutated in dominant deafness. Cell 96:437-446.

Lamas JA, Selyanko AA, Brown DA (1997) Effects of a cognition enhancer, linopirdine (DuP 996), on M-type potassium currents $\left(I_{\mathrm{K}(\mathrm{M})}\right)$ and some other voltage- and ligand-gated membrane currents in rat sympathetic neurones. Eur J Neurosci 9:606-616.

Lerche C, Schere CR, Seebohm G, Derst C, Wei AD, Busch A, Steinmeyer K (2000) Molecular cloning and functional expression of KCNQ5, a potassium channel subunit that may contribute to neuronal M-current diversity. J Biol Chem 275:22395-22400.

London B, Trudeau MC, Newton, KP, Beyer, AK, Copeland NG, Gilbert DJ Jenkins, NA, Satlerm CA, Robertson GA (1997) Two isoforms of the mouse ether-a-go-go-related gene coassemble to form channels with properties similar to the rapidly activating component of the cardiac delayed rectifier $\mathrm{K}^{+}$current. Circ Res 81:870-878.

Malin SA, Nerbonne JM (2000) Elimination of the fast transient in superior cervical ganglion neurons with expression of Kv4.2(W362F): molecular dissection of $\mathrm{I}_{\mathrm{A}}$. J Neurosci 20:5191-5199.

Marrion NV (1997) Control of M-current. Annu Rev Physiol 59:483-504.

Meves H, Schwarz JR, Wulfsen I (1999) Separation of M-like current and ERG current in NG108-15 cells. Br J Pharmacol 127:1213-1223.

Robbins J, Trouslard J, Marsh SJ, Brown DA (1992) Kinetic and pharmacological properties of the M-current in rodent neuroblastoma $\mathrm{x}$ glioma hybrid cells. J Physiol (Lond) 451:159-185.

Schroeder BC, Kubisch C, Stein V, Jentsch TJ (1998) Moderate loss of function of cyclic-AMP-modulated KCNQ2/KCNQ3 $\mathrm{K}^{+}$channels causes epilepsy. Nature 396:687-690.

Schroeder BC, Hechenberger M, Weinreich F, Kubisch C, Jentsch TJ (2000) KCNQ5, a novel potassium channel broadly expressed in brain, mediates M-type currents. J Biol Chem 275:24089-24065.

Selyanko AA, Hadley JK, Wood IC, Abogadie FC, Delmas P, Buckley NJ, London B, Brown DA (1999) Two types of $\mathrm{K}^{+}$channel subunit, Erg1 and KCNQ2/3, contribute to the M-like current in a mammalian neuronal cell. J Neurosci 19:7742-7756.

Selyanko AA, Hadley JK, Wood IC, Abogadie FC, Jentsch TJ, Brown DA (2000) Inhibition of KCNQ1-4 potassium channels expressed in mammalian cells via $\mathrm{M}_{1}$ muscarinic acetylcholine receptors. J Physiol (Lond) 522:349-355.

Shapiro MS, Roche JP, Kaftan EJ, Cruzblanca H, Mackie K, Hille B (2000) Reconstitution of muscarinic modulation of the KCNQ2/ KCNQ3 $\mathrm{K}^{+}$channels that underlie the neuronal M current. J Neurosci 20:1710-1721.

Shi W, Wymore RS, Wang H-S, Pan Z, Cohen IS, McKinnon D, Dixon JE (1997) Identification of two nervous system-specific members of the erg potassium channel gene family. J Neurosci 17:9423-9432.

Wang H-S, Pan Z, Brown BS, Wymore RS, Cohen IS, Dixon JE, McKinnon D (1998) KCNQ2 and KCNQ3 potassium channel subunits: molecular correlates of the M-channel. Science 282:1890-1893. 